\title{
Habitus: An attempt at a thorough analysis of a controversial concept in Pierre Bourdieu's theory of practice
}

\author{
Anna Asimaki ${ }^{1}$, Gerasimos Koustourakis ${ }^{2}$ \\ ${ }^{1}$ Department of Primary Education, University Campus, University of Patras, 265.04 Rio Patras, Greece \\ ${ }^{2}$ Department of Educational Sciences and Early Childhood Education, University Campus, University of Patras, 265.04 Rio Patras, Greece \\ Email address: \\ asimaki@upatras.gr (A. Asimaki), koustourakis@upatras.gr (G. Koustourakis)
}

\section{To cite this article:}

Anna Asimaki, Gerasimos Koustourakis. Habitus: An Attempt at a Thorough Analysis of a Controversial Concept in Pierre Bourdieu's Theory of Practice. Social Sciences. Vol. 3, No. 4, 2014, pp. 121-131. doi: 10.11648/j.ss.20140304.13

\begin{abstract}
This work focuses on the approach to and analysis of the concept of habitus, and on tracing its relationship to the concept of practice within the framework of Pierre Bourdieu's 'theory of practice'. Based on these determinants, we attempted a thorough approach to the concept of habitus. Within the context of epistemological clarification we considered it essential to draw attention to its genealogy and the course of its development. Bearing in mind too the large number of discussions the controversial concept of habitus has provoked in the field of social sciences, we attempted to make reference to the most important relevant critical approaches. In the article's concluding observations, the concept's indisputable contribution to and influence on the field of social sciences is demonstrated, as is the notion that Pierre Bourdieu's constructed concept of habitus attempts to put an end to fundamental divisions in sociology such as: objectivism-subjectivism, individual-society, conscious-unconscious.
\end{abstract}

Keywords: Habitus, Bourdieu, Theory of Practice

\section{Introduction}

Pierre Bourdieu, French Sociologist, professor at the College de France from 1981 until 2001, is recognized world-wide as one of the most important social scientists of the second half of the $20^{\text {th }}$ century (Corcuff, 2007: 26). Without doubt he constituted a 'social fact' in the global field of Social and Humanistic sciences. This is evident from his long-lasting scientific presence which was crowned by the publication of 32 books by 2001 and 216 translations of them, into 27 languages, including Chinese, Estonian and Hebrew, and which is without taking into account hundreds of scientific articles which were published in international scientific journals (Heinich, 2007: 174; Panagiotopoulos, 1992). Another important venture in his country is the publication of the 'Bourdieu Dictionary' the objectives of which are the definition, the explanation and the interpretation of his sociological concepts. Through Pierre Bourdieu's work, his personality and the uniqueness of his theoretical structure, which has a theoretical cohesion since it is supported in a dense net of concepts (Chevalie and Chauvire, 2010: 7-10), become discernable.
Bourdieu's work is far-reaching and multifarious. The diversity, the wideness and the richness of his works may create the impression of a lack of continuity since his opus stretches the breadth of the human sciences and approaches a body of varied and diverse sociological objects (Bonnewitz, 2009: 25). This work covers the scientific fields of Sociology, Anthropology, Philosophy and Economics and approaches traditional societies, contemporary societies, the 'microcosm' of the Universities, the 'microcosm' of haute couture and art, the 'micrcosm' of the mass media, male domination, and the economy (Jourdain and Naulin, 2011: 10; Leledakis, 2006). Bourdieu was especially interested in an approach to the mechanisms of domination and cultural reproduction of social hierarchies, as well as in the connection between individuals social origin with their preferences and practices (Jourdain and Naulin, 2011: 5). It is clear that he constructed a multiform body of work on a variety of objects and fields claiming that it is never possible to separate theory from empirical work (Corcuff, 2007: 26). 
Bourdieu's sociology in the contemporary sociological field is defined by and identified with a body of constructed sociological concepts, the most important of which being the following concepts: habitus, field, cultural capital, practice, symbolic violence, dominance. However, in the field of the social sciences his name is associated not only with 'his conceptual armory', but also with his 'holistic approach'. Bourdieu vigorously claims that Sociology can attain a high level of scientificality and objectivity and that it is the science which can exercise a 'critical function' for revealing social mechanisms and in particular 'dominance'. It appears that his ultimate goal is the construction of a 'whole science', capable of rendering the basic and fundamental unity of acting subjects' practice (Bonnewitz, 2009: 3).

Bourdieu's most central conceptual construct, 'habitus', runs through, gives meaning to and unifies all the aspects of his theoretical framework. This is an 'enigmatic concept', widely used in an exceptionally large number of scientific works (see: Devine 2009; Funnell, 2008; Ingram, 2009; Morrison, 2005; Nash, 2005; Van de Werfhorst, 2010) and by a whole body of scientific fields such as Sociology, Philosophy, Anthropology, Education and Art. However, the concept of habitus gave rise to misunderstandings, was used incorrectly by many scholars, was acutely doubted, received criticism and provoked great disagreements and discussions in the field of the social sciences. Without doubt, this concept can function 'revealingly', but can also confuse matters since it appears to be difficult to define (Maton, 2008). That's why Dortier (2008: 11) notes characteristically: 'don't search Bourdieu's work for a clear definition of habitus'.

The aim of this work is an approach to the concept of habitus and the tracing of its relationship to the concept of practice within the context of Pierre Bourdieu's 'theory of practice'.

The work begins with a schematic outlining of Bourdieu's theory of practice. There follows a thorough approach to the concept of habitus and the criticism leveled at it within the context of the field of the social sciences. The work concludes with some observations of a deductive nature.

\section{The 'Theory of Practice': A Schematic Presentation}

Bourdieu moves beyond an unproductive theoretical point of view as he understands theory as a means of actions which lead to the construction of concepts, which are associated with empirical research and in this way they acquire an explanatory and interpretative capability (Panagiotopoulos, 1995). He proposes, then, a sociology which is carried out empirically but always through 'theoretical purposes (Panagiotopoulos, 1992).

The whole of Bourdieu's theoretical work is opposed to the divisions which characterize as much the social sciences as the field of sociology, such as those between
Sociology and History, Sociology and Ethnology as well as the divisive categories of the social sciences (Sociology of Education, Sociology of Culture and so on), the division of the -isms (such as Marxism, Durkheimism, etc.) and the oppositions between macro-sociology - micro-sociology and theory - methodology. Bourdieu's sociology tries to go beyond these divisions which he considers arbitrary, and which is why he also disagrees with the fundamental opposition objectivism - subjectivism- social physics and social phenomenology (Panagiotopoulos, 1995).

In the field of the social sciences two fundamentally different theoretical dichotomies developed, concerning the issue of the formation of the social world. The objectivist approach, which considers that the structure (unseen relationships and entrenched institutions) exercise force on the individual, and affects his socialization and his integration into the social world, belongs in the first formation. In this case is society and the social context are given priority, and the agent who appears to be merely a carrier of the structures, is downgraded (Panagiotopoulos, 1992; Romanos, 2007). Hence, objectivism forms the social world as 'a spectacle offered to an observer who adopts a point of view against the action' (Bourdieu, 2006: 87). On the other side of this view is the subjectivist outlook. This view promotes the individual whose action is neither produced nor defined by the structure. Conversely, it is produced and defined by the actor himself since he sets objectives, has aspirations and makes choices. Here the structure is restricted and the freedom of the actor takes precedence (Panagiotopoulos, 1992). Bourdieu's Sociology attempts to reconcile this fundamental division of objectivism - subjectivism which so defined and characterized modern thought (Romanos, 2007). In his attempt to resolve this extremely complex issue, and also refer to it in a brief manner, Bourdieu used to paraphrase Pascal's maxim: 'the world shelters and contains me, but I also shelter it in my thought' (Bourdieu, 2000: 27). What's more, he claimed that to approach the question of the formation of the social world and its interpretation only from the viewpoint of objectivism means that we overlook the subjectivist viewpoint since the social world should be approached based on the viewpoint of people's actions as well (Grenfell, 2008; Tatsis, 2004). In other words, it's about sociology's course between two rocks, poles or dualisms, which Bourdieu attempted to surpass with his work (Bourdieu et al, 2007: 420).

Bourdieu formulates his sociological 'paradigm', which is given the name 'constructed or genetic structuralism', based on the uniting, the combining, of objectivism with subjectivism (Corcuff, 2007: 27). He himself claims that if he had to characterize his theory by labeling it, he would state that:

'...saying structuralism I mean that in the social world there are...objective structures independent of the consciousnesses (awareness and desire) of the carriers and capable of orienting - guiding or forcing - restricting their practices or their performances. By the term constructed I 
mean that there is a double social genesis. On the one hand, forms of attitude, thought and action are shaped which are essential elements of what I call hexis-habitus, and on the other, the social structures, what I call fields and groups, mainly what we usually call social classes' (Bourdieu, 1987: 147).

The position above makes clear the complicity of the objectivist and the subjectivist angles, as well as their dialectical relationship. Hence, Bourdieu's sociology avoids 'structural realism', in other words unrestrained determinism, and it makes him relevant exactly through this dialectic relationship (objectivism - subjectivism, structure - action). On the other hand, he doesn't surrender to the subjectivism which ignores the coercion of structures and the 'necessity of the social world'. The question that then arises however concerns which 'space' the dialectic relationship objectivism - subjectivism is expressed within. Bourdieu's answer is to be found in the concept of 'practice', which constitutes 'the space of the dialectics of the structures and hexis-habitus' (Bourdieu, 2006: 88). This means that the individuals' action is located in the dialectical relationship of 'the social', in other words 'objectivified' history, and the incorporated history of 'hexis-habitus', which, according to Bourdieu, takes the form of 'systems of permanent dispositions'. This system of permanent dispositions, which Bourdieu calls 'hexis-habitus' forms, and places in the bodies of the individuals, forms of perception, representation and thought, as well as forms of assessment and evaluation of the social world, which function as 'generative and organizing principles' which tend to define the agents' practices. In any case, the practical world is composed, according to Bourdieu, of the relationship with the hexis-habitus, and the interpretation of the individuals' practices can exist only through a connection that the hexis-habitus effects, and also conceals 'within and through' practice. This connection is to be found in the two conditions of the social world, in the first which concerns the objective social conditions of the agent's existence within which the hexis-habitus, which produced the practices, was shaped, and in the second which concerns the social conditions within which the hexis-habitus is placed and functions. However, the question arises of what defines the practices, in other words, what defines, within the various social situations, the automatic and spontaneous choices of the actors? Are their practices determined mechanically and deterministically? Without doubt, that 'infinite, generative, but also limited controlled free principle, hexis-habitus as a sense of practice' defines them, and it always produces 'logical' behaviours, practices, which are governed nevertheless by a 'logical pracice' (Bourdieu, 2006: 87-95; Panagiotopoulos, 1990). The aforementioned mean that relative freedom is inherent in the individuals' action, and that the actors' practices don't remain as products of hexis-habitus, trapped in the structure. Hence, the individuals which constitute products of the structure, shape and reshape it continuously and consequently can, under certain structural preconditions, transform it, more, or less, radically (Bourdieu, 1984: 173). Although the concept hexis-habitus seems to have been constructed by Bourdieu in order to address the issue of the non conscious or subjugated to rules orientation of practices, it doesn't act alone with regard to the practices (Maton, 2008; McNay, 2002).

The theory of practice is structured based on three concepts, which make up its basic components or the 'Holy Trinity' of Pierre Bourdieu's theoretical model. They are the concepts of Habitus, Field and Capital (Fowler, 1999; Panagiotopoulos, 2003). Practices are understood as the result of an indefinite, unconscious, double relationship between habitus and the field' (Bourdieu, 2003: 147). In order to convey and summarize this relationship, Bourdieu constructed the following model:

$$
[(\text { habitus })(\text { capital })]+\text { field }=\text { practice }
$$

This model reveals that practice stems from the relationship of the individuals habitus and their position (which depends on the amount and structure of their capital) within the social field (Maton, 2008).

We consider it essential to allude to the concepts of field and capital and then define the concept of habitus.

According to Bourdieu, 'the social universes', 'the microcosms', 'the markets', all these technical terms which are created and used by Bourdieu himself to analyse 'the relatively autonomous social worlds which are called fields (such as, for example, the scientific, the political, the athletic, and others)' (Bourdieu, 2005: 24) are defined as structured spaces of positions which the acting subjects occupy according to the principles of differentiation and distribution of resources or capital which they possess (Bourdieu, 1994: 64; Bourdieu, 2000: 157). So, 'the distances', or 'the proximities of the positions', 'the affinities', 'the removals', 'the discords' within the fields are determined by the amount and type of capital the social actors possess (Bourdieu, 1992: 65). In addition, inherent in each field, which constitutes a 'site' of struggle, there is a fight in which the individuals who participate seek to dominate by making use of the different forms and types of capital which they possess (Bourdieu, 1992: 45-46). Indeed the fields constitute 'markets for particular types of capital' which are characteristic of the fields. In addition, each space of positions in each field is occupied by suitable and adapted habit-habitus in the sense of an existence of a harmonious meeting between positions and dispositions (Accardo and Corcuff, 1986: 86; Chauvire and Fontaine, 2003: 17).

The concept of capital in Bourdieu's theoretical model is wide-reaching, multiform and reveals the system of social relationships and dependences which are inherent in all the 'social universes'. Bourdieu, without underestimating the concept of 'economic capital', and the role this plays in social formation and social relationships, extends the concept of capital by constructing other forms, such as cultural, social and symbolic capital (Chauvire and Fontaine, 2003: 15; O'Brien and O'Fathaigh, 2005). More specifically, Bourdieu understands capital as 'accumulated labour', which can 
assume either an embodied form or an objectified form (Bourdieu, 1986: 241). This is also why the forms of capital which the individuals possess determine their positions and capabilities in the various fields (Siisiainen, 2000). Moreover, a 'particular kind of capital' corresponds to each field, and it functions as power and stake within each field (Bourdieu, 1999: 335; Bourdieu and Wacquant, 1996: 76).

Cultural capital is composed of a body of symbolic goods and represents significant symbolic resources such as education, knowledge, skills, family background (Chauviré and Fontaine, 2003: 12). This can exist in three forms. Firstly in the incorporated form, cultural capital appears to be internalized, a registered and integral part of the body in the form of dispositions since it comprises 'a have that became a be, an hexis, a habitus' (Bourdieu, 1994: 78). In addition, cultural capital can exist in the objectified state in the form of goods (works of art, books, paintings etc.). Finally, it can exist in the institutionalized form of educational credentials (Moore, 2008).

Social capital is defined in Bourdieu's analysis as a 'network of permanent and fixed social relationships' of mutual recognition and mutual acquaintance, beneficial and productive for the one who has them and maintains them and which are linked to integration into a group (Bourdieu, 1994: 92; Bourdieu and Wacquant, 1992: 95; Sobel, 2002). Finally, symbolic capital is the meaning conveyed by symbols (all kinds of languages), which becomes discernable and is employed by those categories of acting subjects who are familiar with it, understand it and recognize it, in other words, lend it value (Bourdieu, 1994: 116). In any case, as Bourdieu claims, every kind of capital (economic, cultural, social) can have the tendency to function as symbolic capital if it is recognized expressly and actually, in other words, when it is recognized as 'legitimate power' (Bourdieu, 2002b). Symbolic capital yields the increase in status goods and is linked to the idea that interests are not always necessarily narrowly economic (Bourdieu, 1986: 134; Bourdieu, 1992: 47).

To conclude, Bourdieu constructed the concept of habitus to demonstrate that the habitus of the acting subjects, functioning as an 'internal compass', orients and guides their practices (Panagiotopoulos, 1990).

We will now approach the concept of habitus in an analytical manner.

\section{Moving towards a Definition of the Concept of Habitus: An Important Observation}

We deem it necessary to move on to a distinction between the concepts of 'custom' and 'habit', which Bourdieu used in the course of the development of his theoretic construction before arriving at the concept of habitus based on his sociological studies. He considered this distinction useful in order to avoid and keep in check 'practical mistakes' (Bourdieu, 2002a: 133). More specifically, before the use of the constructed concept of habitus, Bourdieu used the word 'ethos' distinguishing it from the word 'ethics', so as to outline an objectively articulated system of predispositions and generative principles of practice. In order to highlight, in other words, the unconscious, internalized schemata, the principles and the values of the subject, which in the form of predispositions 'govern and guide' his everyday practice. From this point of view, 'ethos' is opposed to 'ethics' (éthique), which comprises an articulated system which is absolutely related to explicit principles and codes (Bourdieu, 2002a: 133).

Bourdieu also used the concept of 'hexis' understood in particular as a point of reference for the body. The 'corporal hexis' (hexis corporelle) comprises an acquired 'physical predisposition' which is expressed and depicted in the way we stand, walk, talk or move the body from one position to another (Bonnewitz, 2009: 78). The body constitutes a 'memorandum' in which, through socialization, the fundamental categories of a world view are registered, mainly in the form of social principles of discrimination (Bourdieu, 1996: 29). For example, decorum, easiness, privation or exuberance, severity, grace or coarseness and so on, which are cultivated through the subject's education, upbringing and socialization, are always elements registered on the body in the form of reactions, gestures or posture (Accardo, 1991: 98).

Consequently, in order to avoid the connotation of habit or automatic mechanical repetition which is contained within the ancient greek terms 'custom' and 'habit', Bourdieu resorts to using the concept of habitus for two reasons. Firstly because the concepts of 'ethos' and 'hexis' constitute two potential dimensions, as well as constituent elements, of it. And secondly, the concept of habitus allows for the possibility of the relative autonomy of the actor in his everyday practices. In other words, habitus appears as the 'mediator' through which the individuals comprehend, evaluate and depict reality. What's more, habitus constitutes, at the same time, the producer of their practices. These two sides are inseparable (Bonnewitz, 2009: 78). Besides, as Bourdieu characteristically points out, the division of habitus into the dimensions of ethos and hexis contains the danger, 'the risk', of fragmenting the concept and strengthening the approach to it from the objectivist point of view only (Bourdieu, 2002a: 133-135).

\section{A thorough Approach to the Concept of Habitus}

Bourdieu doesn't appreciate, as he confesses, the 'professorial definitions' of concepts, in other word, those produced in academic environments and which are characterized by their exhaustiveness and clear bounds. He considers that these definitions are not creative and dynamic. That's why he prefers the 'open concepts' in sociological theory (Moessinger, 1994). Consequently it is not possible to locate a single, distinct and absolutely clear definition of the 
concept of habitus in his theoretical framework (Dortiet, 2008: 11). Hence Bourdieu refers to habitus in a variety of ways considering it to be: a 'product of history', a 'system of continuous and transferable predispositions', 'structured but also structuring structure', 'past which survives in the present and is perpetuated in the future', 'infinite capacity for free (controlled free) manufacture of products', 'art of invention', 'continuous and generative principle of regulated improvisations', 'genetic principle of distinct and distinguishing practices', 'general and unifying principle which reinterprets the essential and relative characteristics of a position', the embodiment of history', 'innate law registered on the body', 'the principle of a selective perception of indicators which tend to confirm it', 'history which became a body', 'product of embodiment', 'embodied history transformed in nature and therefore forgotten as history' (Bourdieu, 1994: 63; Bourdieu, 2000: 21, 22, 158; Bourdieu, 2006: 88-107). Many more of Bourdieu's references to the concept of habitus could be added. Nevertheless, he claims that it is a very 'old' concept which has become active again (Bourdieu and Chartier, 2010: 73-74).

We meet the concept of habitus in the ancient Greek philosopher Aristotle as 'hexis' where it outlines the body positions, capabilities and skills of the individuals. They are elements acquired and embodied during people's education, and which lay the foundations of, and determine, their action. We even find this concept in Saint Thomas d'Aquin, who transformed it and gave it the scientific name of habitus, believing that it constituted a product of socialization where practices 'are registered - imprinted' on the body and which then function as spontaneity in relation to the individual (Jourdain and Naulin, 2011: 33). Bourdieu also refers to Husserl, Mauss, Durkheim and Weber concerning the origin of the concept habitus. However he points out that its 'genealogical perspective' neither offers nor adds anything of significance, since the scientific use of a concept should mainly presuppose a 'practical and theoretical mastery' within the conceptual field that is used (Bourdieu and Chartier, 2010: 74). It wouldn't be inappropriate either to point out that Bourdieu considers the book entitled 'Gothic Architecture and scholastic thought' (Architecture gothique et pensee scolastique) by the German art historian Erwin Panofsky to be confirmation of the theory of habitus. In this book, Panofsky deals with the question of the birth of gothic architecture as a result of the discovery of a 'bond' between the 'scholastic' thought of the architects who produced it (which was a result of their school education) and gothic architecture, in other words, the result of their work. Consequently, the concept of habitus has a long pre-history and while it wasn't 'invented' by Bourdieu, it was without doubt Bourdieu who redefined it, readjusted it, gave it his personal interpretation and mainly a fundamental position within the body of 'conceptual tools' of the science of sociology (Chauvire and Fontaine, 2003: 49; Jourdain and Naulin, 2011: 33-35). But, what is this 'enigmatic' concept of habitus? Based on the references to it above, it is clear that
Bourdieu gave it multiple definitions. Besides, Bourdieu himself claims that the discussion surrounding habitus is extremely complex. However, he believes that this concept is very important and has 'virtues'. Its significance is due to the fact that it reminds us mainly how the social subjects have a history, a 'course of life'. In other words, they constitute the product of an individual history and education absolutely connected to a social environment and moreover are products of a collective history. The set of categories of their intellect and thought, as well as the systems of perception, evaluation and assessment they have, are nothing other than products of the embodiment of social structures (Bourdieu and Chartier, 2010: 74). Among the multiple definitions Bourdieu provided for the concept of habitus, the most comprehensive, most systematic and perhaps the most 'famous' is to be found in his book entitled 'The practical sense' (Le sens pratique). There Bourdieu approaches habitus as follows:

'The external definitions which are connected to a particular class of conditions of existence produce hexis (habitus), systems of continuous and transferable predispositions, structured structures predisposed to function as structuring structures, in other words as generative and organizing principles of the practices and reconstructions, which can be adapted objectively to their purpose without aiming consciously at it, and to control explicitly the actions necessary for its achievement' (Bourdieu, 2006: 88).

In this definition, Bourdieu considers habitus firstly to be a 'system of continuous and transferable dispositions'. When Bourdieu refers to dispositions he means the individuals' positions and tendencies, in terms of the particular way they think, feel, act, understand and which they have embodied and internalized, not in a conscious way, but through pedagogical processes and socializations at the base of the objective social conditions of their existence, but also of their social 'orbit'. These dispositions tend to function as non conscious principles which guide practice, and in general perception, but also every reaction of the individuals (Bonnewitz, 2009: 80; Corcuff, 2007: 29). Hence, the dispositions, as a product of 'social embodiment', constitute neither 'reconstructions', nor 'determinisms definitions', but 'tendencies', which, at the end of the day, emerge and are revealed through the individuals' practice (Grange, 2009). However these dispositions are governed by duration. Habitus, as an embodied internal compass, as a system of dispositions, guides the way in which we act, feel, think and talk. The question which arises is whether all our past experiences and the pedagogical processes we have experienced during our socialization play the same role or, more correctly, have the same weight as far as the structural composition of our personalities is concerned. Bourdieu insists on the view that the dispositions which we acquire during childhood in the field of the family, and which 'implanted' a primary habitus in us, are 'longer lasting' and more decisive. It is clear that the different social environments in which different choices of practices 
predominate also generate different systems of dispositions, in other words, different habitus. Nevertheless this primary habitus doesn't become entrenched or remain undeveloped. Onto it secondary habitus are 'transplanted', like, for example the school or professional. Consequently it would appear that habitus constitutes an internalized structure which is to be found on the road of continuous restructuring' (Accardo, 1991: 90). In addition by the term 'continuous' Bourdieu means that if the positions and tendencies, in other words the dispositions, are likely to alter in the course of the social subjects' acquisition of experiences, at the same time they also tend to be durable. This is because they are internalized, embodied and deeply 'implanted' within them, with the result that they resist change, defining in this way a certain 'continuation', course and way of life. Consequently it becomes clear that the individuals tend to maintain and perpetuate the dispositions 'acquired' through their socialization (Jourdain and Naulin, 2011: 34-35). Despite that, if the objective conditions, in other words, the conditions in the social field, change and the habitus of the individuals cannot adapt due to 'inactivity' it may present, then the ' hysteresis' effect (effet) appears. Bourdieu believes that hysteresis constitutes an objective mechanism through which the tendency to adopt schemata and categories of thought, perception, evaluation and assessment are created, and which correspond to a past situation or time (Bourdieu, 2003: 188; Hurtado, 2010). Under these conditions the individuals act 'clumsily' or make mistakes. In other words, they do 'inappropriate' and 'unsuitable' things. This means that they adopt outdated practices which do not correspond to their present position in the context of the new objective conditions of the social field. In order to convey with precision the phenomenon of hysteresis in habitus, Bourdieu offers the example of Cervantes' hero, Don Quixote who continued behaving like a knight in a world where chivalry no longer existed (Bonnewitz, 2009: 84; Jourdain and Naulin, 2011: 35).

The dispositions are also 'transferable'. This means that the set of dispositions that the agents acquire and possess through their experiences, socializations and generally the course of their life, influences and acts effectively on other, different, contexts of experiences of their lives (Corcuff, 2007: 29). For example, if pessimism or ambition characterize an individual, they are then characteristics which have been 'implanted' in him due to the habitus he has acquired, and this then means that ambition or pessimism will characterize him and will be expressed in a variety of ways depending on the conditions which predominate in the different fields within which he is to be found during his life. What is certain however is that the individual's dispositions will unavoidably be expressed. So, if someone behaves in an ambitious or pessimistic way in the professional field, this implies that he will function in a similar way in the athletic field, or the emotional. From this point of view, the social subjects' dispositions determine, in a 'systematic way' all their practices (Accardo, 1991: 89). This means that they consist partly of, and co-shape, a primary systematic and 'unifying' element of the existence of the individuals. The above demonstrates that habitus is made up of forms of perception and action which are internalized and embodied by the individuals which tend to be connected and ultimately form a 'system' (Corcuff, 2007: 29). Bourdieu's aforementioned definition of habitus also makes it clear that it constitutes a 'structured structure', which tends to function as a 'structuring structure'. In order to convey the concepts of the 'structured and structuring structure' of habitus, Dortier (2008: 12) offered the example of a musician who cannot improvise on the piano if he hasn't learnt the rules of composition and harmony. So, only once he has internalized the 'codes' of music (in the sense of the structured structure), can he improvise and transmit his music (in the sense of a structuring structure). Besides, Bourdieu's (2006: 88) observation on habitus, that it constitutes 'conductorless orchestration' is characteristic. Consequently, habitus doesn't simply reproduce social structures, of which it constitutes a product since it is made up of 'generative and organizational principles'. In order to make clear the generative and organizational dimension of the concept of habitus, Bourdieu uses the analogy of a computer software (a dangerous analogy since it's mechanical). It is a software which tends to self-correct since it is made up of a 'system' of basic principles from which infinite solutions stem. And this without its first basic fundamental principles ever being refuted (Bourdieu, 2002a: 135). In short, habitus, as a system of dispositions, produces practices defined by the objective conditions of existence of the agents who bring them, but it can, according to the circumstances display a power and ability of 'inventions' and be innovative (Corcuff, 2007: 29). This is also the reason why Bourdieu defined the concept of habitus in comparison with the concept of habit (habitude). The latter is defined as the automatic, mechanical repetition of the same behaviour. In other words it is a concept which is mainly reproductive and not productive, as habitus is. Ultimately, Bourdieu insists on the idea that habitus is something 'dynamically generative' (Accardo and Corcuff, 1986: 69; Bourdieu, 2002a: 134).

We consider it essential to point out that that which plays a leading role in the composition and formation of habitus is history. So, habitus appears as a product of history, either some individual's personal history, or the collective - group history of a social class. Consequently there is class habitus and individual habitus, as well as a particular relationship between them, to which Bourdieu gives especial emphasis (Mounier, 2001). In reality he claims that 'every system of individual dispositions (individual habitus) forms a structural variation of others...' (Bourdieu, 2003: 100). Indeed the social habitus constitutes the common denominator in the various practices of an individual actor, as well as the 'common womb' of all the practices of all those actors who lived in the same or similar conditions of existence within the social space (Accardo, 1991: 95-99).

In an attempt to examine the definition of the concept of habitus thoroughly, we consider it essential to focus too on the concept of 'practice'. This is because habitus has two 
dimensions. The first concerns the internalization of exteriority, which takes place through socialization and permits the internalization of social structures by the individual (Bourdieu, 1994: 63-64). In other words, it concerns the relationship of the formation of the internal structures of the subjectivity based on the external objective structures of the individual's existence. Without doubt this internalization involves 'limits', which guide and influence his action. Secondly, habitus permits, as 'structuring structure, as well as generative principle of the practices', the 'externalization of the internality' of the agent. This means that based on the habitus that they have constructed, the agents can shape practices, in given conditions and situations, appropriate and expected by the social context, indeed without the immediate mobilization of their thought or logic (Jourdain and Naulin, 2011: 36). Hence it appears that the individuals' practices aren't simply orders and the execution of explicit social rules. They are governed by a 'practical sense' (sens pratique), which can be defined as a skill related to the way the individual is oriented and acts in a given social situation. In addition his action is influenced by the position he holds in the social field and is expressed spontaneously without falling back often on conscious thoughts. This happens due to his system of dispositions (which were internalized in the past usually in an unconscious way) and which allow him to function in an 'automatic' way. In order to clarify the concept of 'practical sense' Bourdieu offers the example of the tennis player. Without advancing to particularly logical processes, and due to the practical skill he has acquired in relation to the game, it is possible for him as much to predict the available space within which the ball can move as well as respond to the new shots from his opponent's side. Indeed the individuals' practices are not absolutely fixed by the structures provided they have the capacity to make choices. However the individuals practices are not governed by absolute freedom either, since their choices are oriented by the habitus they possess. Hence, free will and objective definitions do not conflict but are to be found in a dialectic relationship (Grange, 2009). Besides there is always an 'economy of practices' which means that their logic isn't to be found either through explicit calculations or through objective external definitions. Conversely, individual action depends on the individuals' habitus, the 'practical sense' of which it constitutes a product and undivided part (Bourdieu, 1987: 156; Bonnewitz, 2009: 80; Corcuff, 2007: 33). Of course, at the same time Bourdieu defines the individual as agent, in other words determined up to a particular point by objective structures, and as a controlled free and independent subject/actor (acteur) who possesses an infinite capacity for creative choices. Consequently, practice in Bourdieu's conceptual 'universe' is nothing other than the space where the objective and the subjective are articulated. In other words, it is the 'field' which can offer us a total view of society (Georgoulas, 2007).

\section{A Critique of the Concept of Habitus}

Without doubt the concept of habitus is a 'controversial' concept in the field of the social sciences, and has provoked a lot of discussion, disagreement, as well as acute criticism. However it is not possible for us to refer to the entire body of discussions and critiques concerning this concept as that would be beyond the aim of this work. For that reason we will make reference to the most important critical approaches concerning habitus.

The most important and most complex critique of Bourdieu concerns the deterministic shade of the concept of habitus. More specifically, Mouzelis (1995) claims that while Bourdieu considers that habitus constitutes a flexible and polysemous concept, he doesn't manage to convince that the connections in his tripartite and interrelated conceptual context 'Field - Habitus - Practice', which ultimately presents the social subject as passive, ignoring the voluntarism and interaction, aren't mechanistic. Mouzelis (1995: 62) arrives at the conclusion that the concept of habitus can prove to be an extremely useful conceptual tool with interpretative and guiding power in empirical research. Taking a similar viewpoint, Margolis (1999: 64-69) claims that while Bourdieu attempts, through the constructed concept of habitus, to avoid and resist the fundamental opposition objectivism-subjectivism in the field of sociology, ultimately he doesn't succeed. He remains trapped in a structuralist viewpoint, where the acting subjects resemble actors, and even in those situations where they improvise when playing a role, their improvisation is governed by the structures. This means that Bourdieu fails to see the 'new text' which the acing subjects construct through improvisation in their everyday practice (micro-sociological theory).

Jeffrey Alexander takes a particularly strict critical stance against the concept of habitus and doesn't hesitate to refer to it as the 'Trojan Horse' of structuralism. He believes that habitus requires the 'passing' of the structure from the visible to the non visible condition, since through a continuous process of cyclical reproduction the objective structures shape the subjective ones and these in turn shape once again the objective structures (Alexander, 2000: 43). According to Alexander, Bourdieu defines the concept in a manner which is unclear, ambiguous and not systematic. So, while it appears to lean towards voluntarism since it permits the acting subjects controlled improvisation, that is to say, improvisation within limits, ultimately it always tends to function in the direction of determinism (Alexander, 2000: 40). To strengthen this position, Alexander claims that in Bourdieu's 'conceptual architecture' the relegation of habitus to the body (hexis corporelle) reveals that he places it in a material place where the internalization of social structures takes place. In this case Bourdieu ignores, despite his claims, the creativity of the acting subject, his critical thought and the significance of the motivation of subjectivity (Alexander, 2000: 51). Consequently, according to Alexander, the concept of habitus doesn't possess an 
internal logic, internal cohesion and autonomy, which could absolutely guide the action without, nevertheless, it being desirable for this to happen in the sense of H. Mead's 'self' or in the sense of T. Parsons' 'personality'. Continuing his criticism, Alexander considers that habitus fails to function as a carrier or vehicle for the connection macro - micro, objectivism - subjectivism (Alexander, 2000: 46).

Another important issue of a critical nature concerning habitus is the capacity of the concept to understand and explain the problem of social change. This is because it is believed that inaction and hysteresis, in other words the concepts which Bourdieu links with habitus, prevent him from classifying a functional conceptual tool, which could describe the important social changes in the world over previous decades (Bonnewitz, 2009: 94). Hence, Calhoun (1995) poses the question of whether the concept of habitus can interpret the individuals' practices in contemporary societies where the individuals are able to act rationally. This is why he believes that habitus has greater interpretative strength for traditional societies, where, due to their conservative structures, the dominant social values, beliefs and positions are transferred more easily to the individuals, because they, due to the social pressure which exists, do not have freedom of choice in the strategies and practices for confronting the various situations they face in their lives. Calhoun (1995) also claims that while the concept of habitus contains and expresses a dynamic in relation to improvisation, creativity and flexibility, in the actors' strategies, it can't ultimately be linked to more general character strategies which could bring about social change. Hence, it remains a 'conservative' concept, which, however, could prove more useful and more interesting if it gave more importance and power to the acting subject.

Finally, Maton (2008) poses an equally crucial and important question which concerns the internal logic of the concept of habitus, which should be analysed and explained further. More specifically, he claims that in order for researchers to reveal the basic elements of habitus they should first approach and analyse the actors' practices, through the recording of their actions across a range of social situations and social structures. What's more, Maton believes that habitus constitutes a very significant conceptual tool for the contemplation of society and that it becomes deficient in the situations where approached and used by the researchers independently and disconnected from the concept of field. This is because when the concept of habitus is not connected to the concept of field, it constitutes plain and simply, as Maton characteristically mentions a 'theoretical cherry on the empirical cake' (Maton, 2008: 63).

Besides, such a broad and inclusive concept as the concept of habitus, is bound to raise a host of unanswered questions which require investigating. So, Accardo (1991: 91) claims that habitus constitutes an internal compass which guides practice and wonders whether all previous experiences of the acting subjects have the same 'weight' for the shaping of their system of dispositions. Within the same context, Di Maggio (1979) poses the question: When is habitus shaped and during its formation are there periods which are more crucial or significant?

Within the context of the criticism which developed around Boudieu's concept of habitus after 1980, a critique emerged in France too related to the novel idea that in the modern world the acting subject is many-faceted, multi-prismed, divided into many parts and non homogenous (l'homme pluriel). Based on the idea above, sociologists like Kaufmann (2001) and Lahire (1998) propose a reinterpretation of the concept of habitus. More specifically, without placing doubt on the fact that the individuals form their dispositions during the process of socialization, they wonder about the unity of those dispositions, their duration in the course of life and their activation within the mass of situations and conditions of contemporary everyday life (Bonnewitz, 2009: 98). So, Lahire (1998) claims that all the more rarely today does the family constitute a means of socialization which is governed by absolute homogeny. On the contrary, he ascertains that in contemporary reality families constitute extremely complex collectives. For example, in one family there may be an illiterate mother, a student brother or a sister who failed at school, and so on. This means that in the child's family environment, different current and future prospects and positions in the social hierarchy, which depend on the family members' different embodiments of dispositions, may be shaped. Lahire (1998) also claims that during their socialization in the modern world, individuals acquire various experiences (e.g. worker/unemployed, woman/wife) and an important role is played by the manner and time of acquisition of these experiences. In other words, the manner in which the individuals acquire experiences contributes to the embodiment, or not, of multiple ways of thinking and forms of action - strategies. It is a body of 'repertoires', which are accessible, appropriate and useful, depending on the social situations. The above demonstrate the plurality of the actors' practices and puts in doubt the distinction and homogeny of the cultural practices, which are suggested by Bourdieu's concept of habitus. Besides, according to Bonnewitz (2009: 99) the idea of the 'non homogenous-multifarious acing subject' (acteur pluriel) constitutes a more complex and open concept than the concept of habitus as an internalized system of dispositions. This idea seems simultaneously to lend greater significance to the rationalism of action and to the interaction of the actors, an element which is not so obvious in Pierre Bourdieu's concept of habitus (Bonnewitz, 2009: 100).

\section{Concluding Observations}

The contribution and influence of Pierre Bourdieu's concept of habitus to the field of social sciences is indisputable. Nevertheless, habitus has come in for severe and excessive criticism, mainly related to its shades of determinism, which can be summarized in the view that Bourdieu confronts the individuals as 'agents' or as 'cultural 
idiots' (idiots culturelles). This is because he considers that when individuals act in the social space, they remain subjugated to and trapped in their habitus, a fact which limits the possibilities of their reactions (Jourdain and Naulin, 2011: 37). Nevertheless, in our opinion, these positions constitute a simplistic approach to habitus. Of course, the concept of habitus, during its primary construction and especially in the work 'Reproduction' (Bourdieu and Passeron, 1970), tended more towards a deterministic outlook carrying the idea that subjective structures are determined by the objective conditions of existence in the social world. This is because this argument permits the predictability and cyclical repetition of the agents' behaviours and practices. Nevertheless, according to Jourdain and Naulin (2011: 37-38), a position which we also adopt in the present work, Bourdieu didn't leave the concept of habitus undeveloped. On the contrary, in the secondary formation of habitus, Bourdieu insists on the dynamic genetic dimension of this concept, assigning it resourcefulness, invention, creativity, discovery and improvisation. In other words, Bourdieu sticks to his belief in the generative capabilities of habitus which he attributes to the actor (Bourdieu, 1987: 583).

To conclude, with the concept of habitus, Bourdieu attempts to put an end to the following traditional and fundamental oppositions and divisions in sociology: Firstly, between objectivism and subjectivism, proposing their dialectic connection. Secondly, the opposition or division individual/society which can be summarized in the phrase 'internalization of the externality, externalization of the internality' (Bonnewitz, 2009: 85). In other words, with the concept of habitus an attempt is made to explain how the outside world passes into the individual - the history which becomes a body - and how the inside passes back out again the history which becomes a thing. Thirdly, the concept of habitus puts an end to the opposition conscious/unconscious mainly through the concept of the sense of practice, which guides, in a non conscious way, the practices of the acting subjects as a 'sensory perception' and 'social necessity' which became nature (second nature) and corporal automation (Panagiotopoulos, 1990).

Habitus, this 'generative grammar' (grammaire generatrice), as Louis Pinto (2004: 51) characteristically names the concept, despite the numerous and various criticism it has come in for, due to the many and different 'readings' of it by social scientists around the world, constitutes a controversial, important and fascinating conceptual construction. This construction continues to remain topical and it will continue to be found at the epicenter of scientific discussion in the field of social, and other, sciences.

\section{References}

[1] Accardo, A. (1991). Initiation à la Sociology. L' illustrationnisme social. Bordeaux: Le Mascaret.
[2] Accardo, A., \& Corcuff, P. (1986). La Sociology de Bourdieu (Textes choisis et comments). Paris: Le Mascaret.

[3] Alexander, J. (2000). La reduction. Critique de Bourdieu. Paris: Les édutions de cerf.

[4] Arnot, M. (2004). Processes of the reproduction of race. Athens: Metaixmio.

[5] Bonnewitz, P. (2009). Pierre Bourdieu vie, oeuvres, concepts. Paris: Ellipses.

[6] Bourdieu, P. (1984). Raisons Pratiques. Paris: Éditions du Seuil.

[7] Bourdieu, P. (1986). The forms of capital. In J. Richardson (Ed.), Handbook of theory and research for the sociology of education (pp. 241-258). New York: Greenwood Press.

[8] Bourdieu, P. (1987). Choses dites. Paris: Éditions de Minuit.

[9] Bourdieu, P. (1992). Microcosms. Athens: Delfini.

[10] Bourdieu, P. (1994). Texts of Sociology. Athens: Delfini.

[11] Bourdieu, P. (1996). Male domination. Athens: Delfini.

[12] Bourdieu, P. (1999). Language and symbolic power. Athens: Kardamitsa.

[13] Bourdieu, P. (2000). Practical discourses for the theory of action. Athens: Plethron.

[14] Bourdieu, P. (2002a). Questions de Sociologie. Paris: Les editions de Minuit.

[15] Bourdieu, P. (2002b). Symbolic capital. Sygxrona Themata, $80,18-21$.

[16] Bourdieu, P. (2003). Distinction. Athens: Patakis.

[17] Bourdieu, P. (2005). For the science and its social uses. Athens: Polytropon.

[18] Bourdieu, P. (2006). The sense of practice. Athens: Alexandreia.

[19] Bourdieu, P., \& Chartier, R. (2010). Le sociology et l' historien. Marseille: Agone.

[20] Bourdieu, P., Chaboredon, J.C., \& Passeron, J.C. (2007). The art of the sociologist. Athens: Metaixmio.

[21] Bourdieu, P., \& Passeron, J.C. (1970). Réproduction. Éléments pour une théorie du système d'enseignement. Paris: Minuit.

[22] Bourdieu, P., \& Wacquant, L. (1992). Réponses. Pour une anthropologie reflexive. Paris: Éditions du Seuil.

[23] Bourdieu, P., \& Wacquant, L. (1996). An Invitation to reflexive sociology. Cambridge: Polity Press.

[24] Calhoun, C. (1995). Habitus, Field, and Capital: The question of historical specificity. In C. Calhoun, E. LiPuma \& M. Postone (Eds.), Bourdieu: Critical Perspectives (pp. 61-87). Cambridge: Polity Press.

[25] Chauviré, C., \& Fontaine, O. (2003). Le vocabulaire de Bourdieu. Paris: Ellipses.

[26] Chevalier, S., \& Chauviré, C. (2010). Dictionnaire Bourdieu. Paris: Ellipses. 
[27] Corcuff, P. (2007). Les nouvelles sociologies. Paris: Armand Colin.

[28] Devine, D. (2009). Mobilizing capitals? Migrant children's negotiation of their everyday lives in school. British Journal of Sociology of Education, 30(5), 521-535.

[29] Di Maggio, P. (1979). Review Essay on P. Bourdieu. American Journal of Sociology, 84(6), 1460-1474.

[30] Dortier, J.F. (2008). Les idées pures n' existent pas. In V. Bedin (Ed.), Pierre Bourdieu: son oevre, son héritage (pp. 7-16). Paris: Sciences Humaines.

[31] Fowler, B. (1999). Pierre Bourdieu's sociological theory of culture. Variant, 2(8), 1-4.

[32] Funnell, F. (2008). Tracing variations within 'rural habitus': an explanation of why young men stay or leave isolated rural towns in southwest Queensland. British Journal of Sociology of Education, 29(1), 15-24.

[33] Georgoulas, A. (2007). Methodological and epistemological presuppositions of a coherent theory of practice. In S. Papaioannou (Ed.), Issues of theory and method of social sciences (pp. 319-337). Athens: Kritiki.

[34] Grange, J. (2009). L' habitus, de la philosophie à la sociology et retour. In M. Lescourret (Ed.), Pierre Bourdieu. Un philosophe en sociology (pp. 33-63). Paris: PUF.

[35] Grenfell, M. (2008). Introduction to Part II. In M. Grenfell (Ed.), Bourdieu: Key Concepts (pp. 43-47). Stocksfield: Acumen.

[36] Heinich, N. (2007). Pourquoi Bourdieu. Paris: Gallimard.

[37] Hutado, P. (2010). Assesing the use of Bourdieu's key concepts in the strategy-as-practice field. Competitiveness Review: An International Business Journal, 20(1), 52-61.

[38] Ingram, N. (2009). Working-class boys, educational success and the misrecognition of working-class culture. British Journal of Sociology of Education, 30(4), 421-434.

[39] Jourdain, A., \& Naulin, S. (2011). La théorie de Pierre Bourdieu et ses usages sociologiques. Paris: Armand Colin.

[40] Kaufmann, J.C. (2001). Ego - Pour une sociologie de l'individu. Paris: Nathan.

[41] Lahire, B. (1998). L'home pluriel-Les resorts de l'action. Paris: Nathan.

[42] Leledakis, K. (2006). 'The sense of Practice': A theory of the social construction of subject, social action and reproduction of the society. In P. Bourdieu, The sense of practice (pp. 432-450). Athens: Alexandreia.

[43] Margolis, J. (1999). Pierre Bourdieu: Habitus and the Logic of Practice. In R. Shusterman (Ed.), Bourdieu: A critical Reader (pp. 64-83). Oxford: Blackwell.

[44] Maton, K. (2008). Habitus. In M. Grenfell (Ed.), Pierre Bourdieu: Key Concepts (pp. 49-65). Scarborough, North Yorkshire: Acumen.

[45] McNay, L. (1999). Gender, Habitus and the Field: Pierre Bourdieu and the Limits of Reflexivity. Theory, Culture \& Society, 16(1), 95-117.

[46] Moessinger, P. (1994). Tentative de clarification de la théorie de Bourdieu. Europian Journal of Sociology, 35(2),324-333.

[47] Moore, R. (2008). Capital. In M. Grenfell (Ed.), Pierre Bourdieu Key Concepts (pp. 101-117). Scarborough, North Yorkshire: Acumen.

[48] Morrison, K. (2005). Structural theory, habitus and complexity theory: elective affinities or old wine in new bottles?. British Journal of Sociology of Education, 26(3), 311-326.

[49] Mounier, P. (2001). Pierre Bourdieu, une introduction. Paris: Agora.

[50] Mouzelis, N. (1995). Habitus: The contribution of Bourdieu in the sociology of action. In I. Lampiri-Dimaki \& N. Panagiotopoulos (Eds.), Sociology of Paedeia (pp. 54-62). Athens: Kardamitsa-Delfini.

[51] Nash, R. (2005). The cognitive habitus: its place in a realist account of inequality/difference. British Journal of Sociology of Education, 26(5), 599-612.

[52] O'Brien, S., \& O'Fathaigh, M. (2005). Bringing in Bourdieu's Theory of Social Capital: Renewing Learning Partnership Approaches to Social Inclusion. ESAI Annual Conference, NUI Maynooth. http://www.docstoc.com/docs/2220018/Bringing-in-Bourdie $\mathrm{u} \% \mathrm{EF} \% \mathrm{BF} \% \mathrm{BDs}$-Theory-of-Social-Capital-Renewing-Lear ning. Accessed 12 April 2014.

[53] Panagiotopoulos, N. (1990). The theory of practice of Pierre Bourdieu. Review of Social Research, 78, 32-65.

[54] Panagiotopoulos, N. (1992). Presentation. In P. Bourdieu P, Microcosms-Three field studies (pp. 7-76). Athens: Delfini.

[55] Panagiotopoulos, N. (1995). Pierre Bourdieu: The thinker of the 'primitive thought' of the thinkers of the 'primitive thought In I. Lampiri-Dimaki \& N. Panagiotopoulos (Eds.), Sociology of Paedeia (pp. 23-48). Athens: Kardamitsa-Delfini.

[56] Panagiotopoulos, N. (2003). The distinction of the 'distinction. In P. Bourdieu, Distinction (pp. 11-50). Athens: Patakis.

[57] Panagiotopoulos, N. (2007). Introductory note: Symbolic violence and social nature. In P. Bourdieu, Male domination (pp. 9-24). Athens: Patakis.

[58] Pinto, L. (2004). Pierre Bourdieu et la théorie du monde social. Paris: Éditions Albin Michel S.A.

[59] Romanos, V. (2007). The live overpowers the dead? Structure, action and subjectivity in Pierre Bourdieu. In S. Papaioannou (Ed.), Issues of theory and method of social sciences (pp. 338-361). Athens: Kritiki.

[60] Siisiainen, M. (2000). Two Concepts of Social Capital: Bourdieu vs. Putnam. In: The Third Sector: For What and for Whom: ISTR Fourth International Conference, July 5-8, 2000, 338-361. http:/dlc.dlib.indiana.edu/dlc/bitstream/handle/10535/7661/ siisiainen.pdf. Accessed 22 February 2014.

[61] Sobel, J. (2002). Can we trust Social Capital? Journal of Economic Literature XL, 139-154.

[62] Tatsis, N. (2004). Sociology. A Historical introduction and theoretical foundations. Athens: Odysseas. 
[63] Van de Werfhorst, H.G. (2010). Cultural capital: strengths, weaknesses and two advancements. British Journal of Sociology of Education, 31(2), 157-169. 